Revista Mexicana de Economía y Finanzas Nueva Época, Vol. 14 No. 1, (2019), pp. 21-40

DOI: http://dx.doi.org/10.21919/remef.v14i1.357

\title{
Non-linear Effects of Ownership Structure, Growth Opportunities and Leverage on Debt Maturity in Chilean Firms ${ }^{1}$
}

\author{
Jorge A. Muñoz Mendoza ${ }^{2}$
}

Universidad de Concepción, Chile

Sandra M. Sepúlveda Yelpo ${ }^{3}$

Universidad de Concepción, Chile

Carmen L. Veloso Ramos ${ }^{4}$

Universidad de Concepción, Chile

(Recepción: 17/abril/2018, aceptado: 14/septiembre/2018)

\section{Abstract}

In this article we analyze the non-linear effect of ownership structure, growth, and indebtedness opportunities on the debt maturity of Chilean companies. A sample of 20,586 companies extracted from the Longitudinal Business Survey was used and a Tobit Regression Model was applied. The results showed that ownership concentration reduced debt maturity. Managerial ownership had a positive and non-linear effect on debt terms, where managerial entrenchment promoted long-term debt for low managerial ownership levels. State ownership had a positive impact on debt maturity. Growth opportunities had a negative impact, while leverage had a positive impact, although their effects are not persistent and depend on the level of these attributes. This study is a pioneer in the use of a wide sample of companies and will allow investors to make better investment decisions since they will be able to identify companies according to these attributes and mitigate the wealth expropriation risk.

JEL Classification: G31, G32, G34

Keywords: Debt maturity, Managerial ownership, State ownership, Growth opportunities, Leverage

\section{Efectos no lineales de la Estructura de Propiedad, Oportunidades de Crecimiento y Leverage sobre la Madurez de la Deuda en Firmas Chilenas}

\section{Resumen}

En este artículo analizamos el efecto no lineal de la estructura de propiedad, oportunidades de crecimiento y endeudamiento sobre la madurez de la deuda en empresas chilenas. Usamos 20586 empresas extraídas de la Encuesta Longitudinal de Empresas y aplicamos un modelo Tobit. Nuestros resultados demuestran que la concentración de la propiedad reduce de la madurez de la deuda. La propiedad gerencial tiene un efecto positivo y no lineal sobre el plazo de la deuda, donde para bajos niveles de propiedad gerencial, el atrincheramiento gerencial promueve la deuda de largo plazo. La propiedad estatal incide positivamente sobre la madurez de la deuda. Las oportunidades de crecimiento tienen un efecto negativo sobre la madurez de la deuda, mientras que el leverage afecta en forma

\footnotetext{
${ }^{1}$ This research was funded by the Office of Research and Development at the University of Concepcion (215.420.003-1.0IN VRID Project).

${ }^{2}$ Assistant Professor, Department of Business Management, University of Concepcion, Los Angeles, Chile. Corresponding author: jormunozm@udec.cl

${ }^{3}$ Assistant Professor, Department of Business Management, University of Concepcion, Los Angeles, Chile. Email: ssepulveday@udec.cl

${ }^{4}$ Professor, Department of Business Management, University of Concepcion, Los Angeles, Chile. Email: carmenveloso@udec.cl

*Fuente de financiamiento: Proyecto VRID Iniciación 215.420.003-1.0 Intitulado "Determinantes de las políticas corporativas en empresas chilenas: Un análisis empírico".
} 
REMEF (The Mexican Journal of Economics and Finance)

Non-linear Effects of Ownership Structure, Growth Opportunities and Leverage on Debt Maturity in Chilean Firms

\section{Resumen}

afecta en forma positiva. Aunque sus efectos no son persistentes y dependen del nivel de estos atributos. Este estudio es pionero en utilizar una amplia muestra de empresas y permitirá a los inversionistas tomar mejores decisiones de inversión ya que podrán identificar las empresas de acuerdo a estos atributos y mitigar el riesgo de expropiación de riqueza.

Clasificación JEL: G31, G32, G34

Palabras clave: madurez, propiedad gerencial, propiedad estatal, oportunidades de crecimiento, leverage

\section{Introduction}

Debt maturity has been a widely investigated subject in corporate finance. Several studies have shown that debt maturity is determined by specific firm characteristics (Myers, 1977; Datta et al., 2005; Benmelech, 2006) as well as structural elements of countries (Joeveer, 2013; Turk, 2016).

Specific company factors, such as ownership structure, and particularly managerial ownership, have been the focus of analysis due to its relevance on debt maturity. The lack of consensus regarding its effects has led researchers to propose different explanations that contrasts the hypothesis of managerial entrenchment suggested by Datta et al. (2005) and Benmelech (2006), where debt maturity increases proportionally with managerial ownership, and the hypothesis of control indicated by Ozkan (2000) and Guney and Ozkan (2005), where debt terms are reduced. Our investigation deepens this discussion and provides an explanation that combines both arguments. Another relevant aspect in this matter is the participation of the State in firms, which has increased since the 2008 financial crisis. This fact has put in the debate the relevance of State capitalism as indicated by Borisova et al. (2012), drawing the interest of researchers towards the effects of State ownership on corporate decisions, such as it is debt maturity decision. International evidence is scarce in this matter and it is non-existent in the case of Chile.

Growth opportunities and debt level are also determining factors for debt maturity. Its effects have been widely discussed, but little consensual. Discrepancies regarding the effects of growth opportunities are explained by a persistent trade-off between underinvestment costs (Myers, 1977; Barclay and Smith, 1995; Ozkan, 2000) and the costs of bankruptcy and liquidity (Diamond, 1991; Childs et al., 2005). Likewise, leverage would have positive as well as negative effects on debt maturity. This is because the relationship between leverage and maturity evaluate the trade-off between overinvestment costs (Barclay et al., 2003) and bankruptcy costs (Leland and Toft, 1996). We believe that the lack of consensus regarding the effects of these factors on debt maturity is due to a non-linear relationship determined by the level of these factors, an aspect that has not been covered in the Chilean literature on this subject.

The objective of our research is to analyze the possible non-linear effects of ownership structure, growth opportunities and debt levels on the debt maturity of Chilean firms. Our research contributes to the existing empirical evidence in three ways. First, we analyzed the non-linear effect of ownership structure, particularly the effects of managerial and State ownership. Regarding the possible non-linear effect of managerial ownership, we sought to contrast whether this is a means of entrenching administrators or aligning them with the interests of company owners. This fact is relevant in Chile as it is a country governed by civil law and, therefore, debt maturity can be transformed into a means of mitigating conflicts of interest between owners and managers. State ownership analysis and its effect on debt maturity is an unprecedented factor for the Chilean and Latin American market. Our focus was to verify whether the participation of the State in firm ownership is a means of guaranteeing access to long-term debt. Second, we studied 
the eventual non-monotonous effect of growth opportunities as a way to contrast the trade-off between underinvestment costs and bankruptcy costs. Third, we analyzed the effect of debt levels on debt maturity, focusing on the trade-off between overinvestment costs and bankruptcy costs, as well as the differences of this trade-off between small and large firms.

We used a sample of 20,586 firms obtained from the Longitudinal Business Survey (LBS). The sample used in this study differentiates our research from previous works carried out in Chile, since we included companies of different sizes, structures and productive sectors. Our results indicate that managerial and State ownership foster long-term debt. Our results show that managers entrenchment to avoid exposure to external financiers, while the role of the State in corporate ownership fosters access to long-term financing. Non-linearity in these variables suggests that the described effects are reversed for high levels of managerial and State ownership. Growth opportunities were found to have a negative and non-linear impact on debt maturity, which supports the existence of a trade-off between underinvestment and bankruptcy costs. In terms of debt, the non-linear effect ratifies the trade-off between overinvestment and bankruptcy costs. This trade-off favors long-term debt in small firms and encourages short-term debt in large firms.

The remainder of this article is structured as follows: Section 2 reviews literature concerning the effects of ownership structure, growth opportunities and debt levels on debt maturity. This section also presents the hypotheses. Section 3 presents the data and analysis methodologies used in this research. Section 4 shows the results obtained. Finally, section 5 presents the conclusions of our study and recommendations for future research.

\section{Theoretical framework and hypothesis}

\subsection{Effects of ownership structure on debt maturity}

Ownership structure plays a fundamental role in corporate debt maturity decisions and its scope can hardly be separated from agency theory. Jensen and Meckling (1976) suggested that, when firms face higher agency costs, ownership structure can be used to mitigate them. This route implicitly impinges on corporate debt maturity. Along this line, Leland (1998) and Lasfer (1999) pointed out that firms reduce debt maturity when they face greater conflicts of interest between the administrator and the owner. Other investigations have corroborated this hypothesis and have argued that this control policy helps mitigate underinvestment or overinvestment practices developed by managers (Myers, 1977; Barnea et al., 1980; Harris and Raviv, 1991; De Angelo et al., 2002; Guney and Ozkan, 2005).

During the last few decades, the empirical literature has studied the relationship between ownership structure and corporate debt maturity in greater detail. Ozkan (2000), Guney and Ozkan (2005) and Jiraporn and Tong (2008) pointed out that the ownership concentration and debt maturity reduction would be a substitute means to control agency costs associated with managerial discretion. Datta et al. (2005) corroborated this view, arguing that firms shorten debt maturity when administrators have high participation in the firm ownership. In their opinion, this is because manager interests are aligned with those of other owners and the benefit of expropriating wealth is reduced. García and Martínez (2010), in a study of 67 Spanish firms, between 1995 and 2001, also argued that the negative relationship described was observed only when the company managers had a high level of participation in corporate ownership. This fact reflects the low incentives to underinvest or overinvest. In any case, Alcock et al. (2011) delved into this line and explain that as manager interests are more aligned with those of the owners, the negative relationship between the ownership concentration and debt maturity is reduced.

A preference for lengthening debt maturity is observed when managerial ownership is low. Arslan and Karan (2006), in a study conducted on 134 Turkish firms, between 1997 and 2003, showed that an increase in managerial ownership, or the presence of a con- 
REMEF (The Mexican Journal of Economics and Finance)

Non-linear Effects of Ownership Structure, Growth Opportunities

trolling shareholder, significantly increased debt maturity. Marchica (2008) corroborated this finding and argued that, when managerial ownership is low, managers prefer longterm debt as a way to mitigate bankruptcy risks and reduce the likelihood of losing their corporate position. Along this line, Datta et al. (2005), Benmelech (2006), Harford et al. (2008) and Tanaka (2015) found a similar relationship, although they warned that this was due to the fact that managers with low ownership prefer to increase debt maturity as a way of isolating themselves from the supervision of external financiers and entrench corporate management rather than mitigate bankruptcy risks. Other investigations concur with this last viewpoint known as managerial entrenchment (Shleifer and Vishny, 1986; Berger et al., 1997; Gompers et al., 2003).

Few studies exist in Chile related to debt maturity. Azofra et al. (2004) and Saona and Vallelado (2005) pointed out that ownership concentration generates a reduction in debt terms as a way to impose better supervision on company administration. However, the authors clarified that their results varied according to how debt maturity was measured. Saona and Vallelado (2014) compared Chilean and Spanish companies and found that when the corporate ownership of banks increases, managers shorten debt maturity as a means of corporate governance and monitoring. More recently, Castañeda and Contreras (2017) carried out a study for companies listed on the stock exchange, although they did not incorporate the effects of ownership structure into their study. In any case, returning to the findings described by empirical evidence, the fact that debt maturity is reduced when corporate managerial ownership is high and increases when it is low could be due to a non-linear effect exerted by managerial ownership on debt maturity (García and Martínez, 2010). This fact has not yet been investigated in Chile and, therefore, we formulated the following hypothesis:

\section{H1: Managerial ownership has a non-linear effect on debt maturity}

Regarding the role of ownership structure, one issue that has attracted recent interest is the effect of State ownership. In fact, State ownership in companies increased significantly as a result of the subprime crisis (Borisova et al., 2015, Megginson, 2017). Megginson (2010) pointed out that many countries have started a privatization process to reverse this trend and to reduce the role of the state in companies. However, its effects have rarely been investigated, especially those related to corporate decision making.

Several studies have shown that short-term debt increases supervision by external financiers (Rajan and Winton, 1995; Park, 2000; Datta et al., 2005). However, in firms with State ownership, the State could acts as a guarantor against possible financial breaches. In this context, the State ownership could alter debt costs and reduces corporate governance quality for companies, mainly in countries governed by civil law (Borisova and Megginson, 2011; Borisova et al., 2012; Borisova et al., 2015). Even so, firms with State ownership could access long-term debt with lower collateral requirements. International evidence along these lines is scarce. Choi (2015) showed that State ownership has a positive and significant effect on corporate debt maturity in an empirical analysis of Chinese firms. Boubakri and Saffar (2017) corroborated these results in a study applied to firms from 62 countries, between 2001 and 2014, arguing that State ownership in companies makes requirements for access to debt financing more flexible. In Chile, there are no studies that analyze the effects of State ownership on debt maturity and therefore we established the following hypothesis:

\section{H2: State ownership has a positive effect on debt maturity}

\subsection{Effects of growth opportunities on debt maturity}

Several international studies have analyzed the effects of growth opportunities on corporate debt maturity. However, there is still no general consensus on this relationship due to the existence of a trade-off between underinvestment and bankruptcy costs. 
Revista Mexicana de Economía y Finanzas Nueva Época, Vol. 14 No. 1, (2019), pp. 21-40 DOI: http://dx.doi.org/10.21919/remef.v14i1.357

Some studies in the literature state that growth opportunities negatively affect debt maturity. Under the underinvestment hypothesis formulated by Myers (1977), it was shown that developmental practices of unprofitable projects carried out by the ownermanager block increase as growth opportunities increase. This policy expropriates bondholder wealth, triggering the agency shareholder-bondholder problem. However, incentives to underinvest can be mitigated if firms finance growth opportunities through short-term debt. Several studies have corroborated the validity of this hypothesis. Titman (1992) explained that companies with greater growth opportunities faced a higher risk of bankruptcy. In this context, the validity of the underinvestment hypothesis lies in the fact that companies benefit from short-term debt not only because it controls agency costs but also because of a reduction in financing costs. Aivazian et al. (2005) also corroborated these findings, arguing that the negative relationship between long-term debt and growth opportunities is more pronounced when these cannot be anticipated in advance. The authors have noted that, in these cases, the information asymmetry content of long-term debt increases the incentives to underinvest. Others research has supported these results and has pointed out that the trade-off between underinvestment costs and liquidity risks tends to favor the first (Kim and Sorensen, 1986; Barclay and Smith, 1995, 1996; Stohs and Mauer, 1996; Guedes and Opler, 1996; Demirguc-Kunt and Macsimovic, 1999; Scherr and Hulburt, 2001; Ozkan, 2000, 2002; Barclay et al., 2003; Johnson, 2003; Benmelech, 2006; Arslan and Karan, 2006; Billet et al., 2007; García and Martínez, 2010; Orman and Köksal, 2017).

Another group of studies found in the literature describes a positive relationship between debt maturity and growth opportunities. Diamond (1991) argued that when firms have greater growth opportunities, the discretionary behavior of managers in relation to these opportunities leads companies to issue long-term debt as a way to mitigate liquidity and bankruptcy risk. Along this same line, Hart and More (1995) and Childs et al. (2005) added that long-term debt can prevent managers from financing unprofitable projects by limiting their future financing capacity. This policy also helps to mitigate the risk of bankruptcy. Other studies have corroborated this view in several countries, such as the United States (Datta et al., 2005; Alcock et al., 2011), the United Kingdom (Antoniou et al., 2006; Dang, 2011) and Italy (Domenichelli, 2015). This view has also been corroborated in international comparisons among various countries (Fan et al., 2010; Chang et al., 2011; Kirch and Soares, 2012; Turk, 2016; Boubakri and Saffar, 2017).

In Chile, there is little evidence in this area and the existing findings are partially contradictory. On one hand, Azofra et al. (2004) indicated that firms with greater growth opportunities financed their investment set with long-term debt, a fact that is consistent with the bankruptcy risk mitigation hypothesis. However, when companies belonged to corporate holdings, they developed an internal capital market that allowed them to finance their investments with short-term debt and with lower costs than those existing in the market. On the other hand, Saona and Vallelado (2005) and Castañeda and Contreras (2017) showed that firms with greater growth opportunities shortened debt terms, endorsing the underinvestment hypothesis.

In any case, international evidence clearly points out that the effects of growth opportunities on debt maturity depend on trade-offs between underinvestment costs and bankruptcy risks. Myers and Majluf (1984) pointed out that, when growth opportunities are low, firms will prefer to finance their investments with short-term debt. If these options are high enough to compensate for information asymmetry costs, firms could issue long-term debt and even equity. This suggests that growth opportunities have a non-linear effect on corporate debt maturity and, therefore, we formulated the following hypothesis:

H3: Growth opportunities have a non-linear effect on debt maturity 
REMEF (The Mexican Journal of Economics and Finance)

Non-linear Effects of Ownership Structure, Growth Opportunities

\subsection{Effects of capital structure on debt maturity}

Debt level can also affect debt terms. Although empirical evidence has shown a lack of consensus regarding this relationship, recent research has revealed that debt levels are relevant when quantifying their impact on debt maturity. Regarding this lack of consensus, Johnson (2003) pointed out that the relationship between firms debt levels and debt maturity depends on the trade-off between the risk of non-optimal investment policies and bankruptcy. Alcock et al. (2011) pointed out that said trade-off may change if firms incorporate their need to reduce financing costs in the debt maturity decision. This fact modifies the ways firms react to bankruptcy risks. These arguments corroborate the fact that debt levels can have positive or negative effects on debt maturity.

Some studies have argued that debt level has a negative effect on debt maturity. Jensen (1986) asserted that agency costs derived from overinvestment practices lead companies to issue debt as a way to mitigate these costs and align manager interests to those of the owners. In this context, debt issued expose administrators to external supervision, inhibiting their discretionary behavior. This debt control effect could be replaced by lower debt maturity (Billet et al., 2007). Barclay et al. (2003), in a study of 5765 companies in the United States, found evidence of a negative and significant relationship between debt level and debt maturity. Their findings showed that firms issue shorter-term debt to control overinvestment or underinvestment problems (Alcock et al., 2012). Jensen (1986) added that problems of non-optimal investments are observed in firms with low debt levels. However, Alcock et al. (2011) warned that a negative relationship between leverage and debt maturity is also observed when debt levels are high. In the opinion of these authors, this context causes a greater probability of default that leads companies to issue shortterm debt to offset this risk. Debts issued contain covenants that significantly reduce additional debt costs, guaranteeing a company's ability to pay.

Other investigations have contradicted this view, endorsing a positive relationship between debt levels and debt maturity. Leland and Toft (1996) pointed out that this relationship is explained by a greater preference of firms to mitigate bankruptcy risk. Morris (1992) added that firms opt for such a policy when their debt levels are high, thus increasing the probability of paying their creditors. Several international studies support this view (Diamond, 1991; Stohs and Mauer, 1996; Datta et al., 2005; Antoniou et al., 2006; Benmelech, 2006; Hackethal and Jansen, 2006; Körner, 2007; Soares, 2009; García and Martínez, 2010; Dang, 2011; Alcock et al., 2011, 2012). In Chile, Muñoz and Sepúlveda (2016) showed that a positive relationship exists between debt level and debt maturity, a fact that reflects the preference to mitigate bankruptcy risk. However, Alcock et al. (2011) pointed out that this type of relationship can only be observed if the debt lacks a covenant. The authors added that, in this case, companies accept mitigating bankruptcy risks by accepting higher debt costs.

The trade-off between non-optimal investment and bankruptcy costs suggests that the relationship between debt levels and debt maturity is non-linear. However, the form of non-linearity depends on whether firms face the risk of bankruptcy issuing debt with or without covenants (Alcock et al., 2011). When firms issue debt without covenants, the costs of non-optimal investment policies force companies to reduce debt maturity when their level of debt is low, while the risk of bankruptcy leads them to increase the debt term when debt level is high. In this case, the relationship between leverage and debt maturity would be U-shaped (Hackethal and Jansen, 2006). When firms issue debt with covenants, this relationship would be in the form of an inverted U. Thus, firms mitigate bankruptcy risks by issuing long-term debt when their debt level is low and benefit from lower costs of short-term debt when their debt level is high. In Chile, this relationship has not been investigated despite the restrictive characteristics of financial regulations that govern the bank and corporate debt issuances. This leads us to formulate the following 
Revista Mexicana de Economía y Finanzas Nueva Época, Vol. 14 No. 1, (2019), pp. 21-40

hypothesis:

\section{H4: Debt level has a non-linear effect on debt maturity}

The relationship between debt level and maturity could be affected by firm size. Joeveer (2013) pointed out that the way in which financing policy is defined differs between small and large firms. Small firms financing policy tend to respond more to specific factors of countries, such as economic growth cycle, rather than to their own factors. This financing is mainly short-term debt and banking debt (Mokhova and Zinecker, 2014). Large company debt depends more on specific firm characteristics that allow them to access long-term financing sources. Demirguc-Kunt and Maksimovic (1999) pointed out that large companies access long-term financing through participation in capital markets. The authors added that capital market development does not affect small company financing.

In Chile, the financial system is significantly oriented towards banking and faces significant levels of information asymmetry regarding companies. According to Saona et al., (2014), this context makes small businesses more dependent on bank financing. However, the greater degree of information asymmetry associated with small companies raises financing costs, increasing their liquidity risk. Companies take out long-term loans to mitigate this problem. On the contrary, for large companies, overinvestment problems and lower growth prospects mean that debt and maturity constitute another way of mitigating this problem. These differences led us to formulate the following hypothesis:

\section{H5: Debt has a positive (negative) effect on debt maturity for small (large) firms.}

\section{Data and methods}

\subsection{Sample of data}

The data used in this investigation were extracted from the Longitudinal Business Survey (hereinafter LBS) prepared by the Ministry of Economy, Development and Tourism in Chile. The data are based on four versions of this survey, which are denoted as LBS1, LBS2, LBS3 and LBS4. These surveys represent business information for the years 2007, 2009, 2013 and 2015, respectively. Table 1 summarizes the variables used in this investigation. The information collected from the LBS is related to business, finance and accounting. However, the LBS does not provide market information.

Samples were organized into a pooled data set composed of 20,586 firms. This sample consisted of 6,647 firms drawn from LBS1, 3,882 from LBS2, 4,190 from LBS3 and 5,867 from LBS4. Companies with incomplete records or that belonged to the financial sector were not considered in the sample.

Debt Maturity (DM) is the dependent variable, measured by long-term debt to total debt ratio. This measurement has been widely used in empirical studies to measure corporate debt terms (Stohs and Mauer, 1996; Datta et al., 2005; Antoniou et al., 2006; Dang, 2011; Alcock et al., 2011).

Regarding ownership structure variables, we used three dummy variables which adopted the 1 value depending on the manager role in a company's ownership structure: owner/manager (OS1) if the manager owns $100 \%$ of the company, partner/manager (OS2) if the manager is one of the owners of the company and outside/manager (OS3) if the manager has no ownership in the firm. The effect of these variables is complemented by the managerial ownership percentage (MO). These types of variables have been suggested by several international studies as a way of measuring the potential effects of aligned interests between managers and owners or managerial entrenchment on debt maturity (Jensen and Meckling, 1976; Ozkan, 2000; Guney and Ozkan, 2005; Datta et al., 2005; Benmelech, 2006; Harford et al., 2008). We also considered the role of State ownership (SO) as a way of verifying whether the State's participation in corporate ownership was 
REMEF (The Mexican Journal of Economics and Finance)

synonymous with financial support, allowing companies to access long-term debt (Choi, 2015; Boubakri and Saffar, 2017).

\begin{tabular}{|c|c|c|}
\hline & Variable & Description \\
\hline \multicolumn{3}{|c|}{ Dependent variable } \\
\hline $\mathrm{DM}$ & Debt Maturity & Long-term debt to total debt ratio \\
\hline \multicolumn{3}{|c|}{ Ownership structure } \\
\hline OS1 & Owner/manager & Dummy 1 if the manager owns the company and 0 otherwise \\
\hline OS2 & Partner/manager & Dummy 1 if the manager is a company partner and 0 otherwise \\
\hline MO & Managerial ownership & Percentage of managerial ownership, where manager is a partner \\
\hline OS3 & Outside/manager & Dummy 1 if the manager has not ownership in the firm and 0 otherwise \\
\hline $\mathrm{ST}$ & State & Dummy 1 if the State has ownership in the company and 0 otherwise \\
\hline $\mathrm{SO}$ & State ownership & State ownership percentage \\
\hline \multicolumn{3}{|c|}{ Growth Opportunities } \\
\hline $\mathrm{GO}$ & Growth in sales & Annual percentage change in sales \\
\hline \multicolumn{3}{|c|}{ Capital Structure } \\
\hline LEV & Corporate debt & Debt to equity ratio \\
\hline \multicolumn{3}{|c|}{ Other control variables } \\
\hline $\mathrm{AC}$ & Agency costs & Operational expenses to sales ratio \\
\hline $\mathrm{FP}$ & Firm Profitability & Return on assets ratio \\
\hline EM & External monitoring & Commercial relationship with external financiers in years \\
\hline FQ & Firm quality & Financial solvency measured by Z-Score \\
\hline SIZE & Firm size & Natural logarithm of total assets \\
\hline $\mathrm{HD}$ & Holding & Dummy 1 if the firm belongs to a business holding and 0 otherwise \\
\hline TANG & Tangibility & Long-term assets to total assets ratio \\
\hline
\end{tabular}
Source: Own elaboration.

The empirical literature has used company growth opportunities as a way to quantify the effects of the trade-off between underinvestment and bankruptcy costs over corporate debt maturity (Myers, 1977; Barclay and Smith, 1995; Arslan and Karan, 2006; García and Martínez, 2010). Growth opportunities are commonly measured through indicators such as Tobin's Q and price-earnings ratios per share, which quantify the impact of future company growth. However, in our investigation, we measured these options through annual sales growth (GO). Danbolt et al. (2011) argued that current growth measurements, based on accounting information, are positively and significantly correlated with future firm growth. This, in addition to the fact that LBS does not provide market information such as with the Tobin's Q, justifies the use of this proxy.

Capital structure (LEV), measured by the debt to equity ratio, is another factor used to control debt maturity. This variable is used to quantify the impact of the trade-off between the costs of overinvestment and liquidity risk (Diamond, 1991; Stohs and Mauer, 1996; Barclay et al., 2003; Datta et al., 2005; Antoniou et al., 2006; Billet et al., 2007; Alcock et al., 2012).

Other debt maturity control variables are also included which have been suggested by various investigations. Agency Costs (AC) measures the effects of managerial discretion in the principal-agent conflict (Leland, 1998; Lasfer, 1999). Per the recommendations of Ang et al. (2000) and Fleming et al. (2005), we will measure agency costs using the operational expenses to sales ratio.

Other control variables that have been suggested by empirical studies are firm credit quality (Flannery, 1986; Diamond, 1991; Dang, 2011), firm profitability (Barclay et al., 2003), external monitoring (Ang et al., 2000), firm size (Benmelech, 2006; Alcock et al., 2011), and asset tangibility (Stohs and Mauer, 1996; Scherr and Hurlburt, 2001). 


\subsection{Econometric method}

Diverse studies analyzed the debt maturity and used various econometric techniques for modeling this variable. Studies based on panel data, formed by stock exchange listed firms and those compare different markets, have mostly used GMM estimators for dynamic models or fixed-effect models (Körner, 2007, Antoniou et al., 2006; and Soares, 2012; Saona and Vallelado, 2005, 2014). The reason for using this type of model is not only due to the type of data structure, but also because the stock exchange listed firms have a debt maturity that will always be between 0 (only short-term debt) and 1 (only long-term debt), but will not reach any of these limits.

Other studies use the Tobit model proposed by Tobin (1958). These studies have used data that includes both large and small companies, and normally organized in cross section data (Johnson, 1997, Muñoz and Sepúlveda, 2016). Following the suggestions of Amemiya $(1984,1985)$, we used the Two-Limit Tobit Regression (TLTR) to estimate the effects of ownership structure, growth opportunities and debt on the corporate debt maturity of Chilean firms. This is due the firm characteristics, mainly SMEs, allow us to visualize the total use of short or long-term debt. The general model is as follows:

$$
y_{i}^{*}=\beta^{\prime} x_{i}+\varepsilon_{i}
$$

Where $y_{i}^{*}$ is the latent dependent variable measured by debt maturity (DMi). In addition, $\beta$ is a coefficients vector and $x_{i}$ is the exogenous variables matrix. If $y_{i}$ is the debt maturity observable into the interval $[0,1]$ we have:

$$
y_{i}=\left\{\begin{array}{l}
L_{1 j}=0 \quad \text { if } \quad y_{i} \leq L_{1 j} \\
y_{i}^{*} \text { if } L_{1 j}<y_{i}^{*}<L_{2 j} \\
L_{2 j}=1 \quad \text { if } \quad y_{i}^{*} \leq L_{2 j}
\end{array}\right.
$$

Where $L_{1 i}$ and $L_{2 i}$ are the lower and upper limits, respectively. Now, the empirical model that evaluates the effects of the ownership structure, growth opportunities and leverage on debt maturity is:

$$
\begin{gathered}
\beta^{\prime} x_{i}=\beta_{0}+\beta_{1} O S_{I}+\beta_{2} M O_{i}+\beta_{3} M O_{i}^{2}+\beta_{4} S O_{i}+\beta_{5} S O_{i}^{2}+\beta_{6} G O_{i}+\beta_{7} G O_{i}^{2}+ \\
\beta_{8} L E V_{i}+\beta_{9} L E V_{i}^{2}+\beta_{10} F Q_{i}+\beta_{11} F P_{i}+\beta_{12} A C_{i}+\beta_{13} E M_{i}+\beta_{14} S I Z E_{i}+\beta_{15} H D_{i}+ \\
\beta_{16} T A N G_{i}+\beta_{17} D Y \text { ear }+\beta_{18} D \text { Sector }
\end{gathered}
$$

$D M_{i}$ is the dependent variable and represents the debt maturity of company i. Debt maturity is measured by the long-term debt to total debt ratio, which restricts this variable to the $[0,1]$ interval. $O S_{i}$ is ownership structure, defined by the three dichotomous variables described in table 1. Managerial ownership is included $\left(M O_{i}\right)$ and its square too $\left(M O_{i}^{2}\right)$. The latter is used to incorporate the non-monotonicity of the managerial ownership effect. Similarly, we controlled the model through State ownership $\left(S O_{i}\right)$ and its square $\left(S O_{i}^{2}\right)$. The $G O_{i}$ variable corresponds to growth opportunities, where $G O_{i}^{2}$ is the square, $L E V_{i}$ is the capital structure of the company and, accordingly, $L E V_{i}^{2}$ is the square of this variable.

The model indicated in $(3)$ includes firm credit quality $\left(F Q_{i}\right)$, firm profitability $\left(F P_{i}\right)$, agency costs $\left(A C_{i}\right)$, external monitoring $\left(E M_{i}\right)$, firm size $\left(S I Z E_{i}\right)$, the dummy variable which measures firm that belongs to business conglomerate $\left(H D_{i}\right)$ and asset tangibility $\left(T A N G_{i}\right)$ as explanatory variables. Finally, $\varepsilon_{i}$ is a random disturbance.

To estimate the effects of capital structure on debt maturity according to firm size and its relation with high growth opportunities, we used a Two-Limit Tobit Regression model (TLTR). The empirical model is the following:

$$
\begin{gathered}
\beta^{\prime} x_{i}=\beta_{0}+\beta_{1} O S_{I}+\beta_{2} M O_{i}+\beta_{3} M O_{i}^{2}+\beta_{4} S O_{i}+\beta_{5} S O_{i}^{2}+\beta_{6} G O_{i}+\beta_{7} L E V_{i}+\beta_{8}\left(L E V_{i} \times\right. \\
D S I Z E)+\beta_{9}\left(L E V_{i} \times D H G\right)+\beta_{10}\left(L E V_{i} \times D H G \times D S I Z E\right)+\beta_{11} F Q_{i}+\beta_{12} \mathrm{FP}_{i}+ \\
\beta_{13} \mathrm{AC}_{i}+\beta_{14} \mathrm{EM}_{i}+\beta_{15} \mathrm{SIZE}_{i}+\beta_{16} \mathrm{HD}_{i}+\beta_{17} \mathrm{TANG}_{i}+\beta_{18} D Y \text { Yar }+\beta_{19} \text { DSector }
\end{gathered}
$$


REMEF (The Mexican Journal of Economics and Finance) Non-linear Effects of Ownership Structure, Growth Opportunities

$D M_{i}$ is the dependent variable representing the debt maturity of companies i. The control variables in (4) have the same definition as those used in model (3). Note that we have included several iterative controls in (4). The iterative variable $\left(L E V_{i} \times D S I Z E\right)$ shows the effect of debt level on debt maturity according to firm size, where DSIZE is a dummy variable that adopts a value of 1 when the company is small (also defined in parallel for large firms) and 0 otherwise. According to Dang (2011), the iterative variable $\left(L E V_{i} \times D H G\right)$ shows the effect of debt level on debt maturity when the firm has a high level of growth opportunities. DHG is a dummy variable that adopts a value of 1 when the firm has high growth opportunities. The definition of this variable considers firms whose sales grow above the average of their sector as high growth companies. Finally $\left(L E V_{i} \times D H G \times D S I Z E\right)$ shows the effect of capital structure on firms with high growth opportunities according to size.

Both models (3) and (4) are controlled through dummy variables which measure differences between productive sectors (DSectori) as well as survey year (DYear). We used robust variances to control heteroscedasticity patterns. The models (3) and (4) are estimated by Maximum Likelihood (ML), being the likelihood function:

$$
\begin{gathered}
L\left(\beta, \sigma \mid y_{i}, x_{i}, L_{1 i}, L_{2 i}\right)= \\
\prod_{y_{i}=L_{1 i}} \Phi\left(\frac{L_{1 i}-\beta^{\prime} x_{i}}{\sigma}\right) \prod_{y_{i}=y_{i}^{*}}\left\{\frac{1}{\sigma} \phi\left(\frac{y_{i}-\beta^{\prime} x_{i}}{\sigma}\right)\right\} \prod_{y_{i}=L_{2 i}}\left\{1-\Phi\left(\frac{L_{2 i}-\beta^{\prime} x_{i}}{\sigma}\right)\right\}
\end{gathered}
$$

Where $\Phi(\mathrm{ffl})$ denotes the cumulative probability function for standard normal distribution, $\phi(\mathrm{ffl})$ denotes the probability density function for standard normal distribution and $\sigma$ is the standard deviation of $\varepsilon_{i}$ term. In this way, the expected value for debt maturity will be given by:

$$
E\left(y_{i} \mid L_{1 i}<y_{i}^{*}<L_{2 i}\right)=\beta^{\prime} x_{i}+E\left(\varepsilon_{i} \mid L_{1 i}-\beta^{\prime} x_{i}<\varepsilon_{i}<L_{2 i}-\beta^{\prime} x_{i}\right)=\beta^{\prime} x_{i}+\sigma\left(\frac{\phi_{1 i}-\phi_{2 i}}{\Phi_{1 i}-\Phi_{2 i}}\right)
$$

Where $\Phi_{1 i}$ and $\Phi_{2 i}$ represent the probability density functions evaluated in the lower and upper limits. Analogously, $\Phi_{1 i}$ and $\Phi_{2 i}$ represent the accumulated probability functions.

\section{Results}

\subsection{Descriptive analysis}

Table 2 shows the sample descriptive analysis. It is observed that the debt maturity oscillates between 0 and 1, that is, between $0 \%$ and $100 \%$ long-term debt to total debt, with an average of 0.1902 . This result indicates that $19.02 \%$ of corporate debt is long-term. In addition, this characteristic of the debt maturity variable allows use Tobit model.

It should be noted that the variables defined through dummies adopt the value 1 when they have a specific quality and 0 otherwise. For this reason, their averages indicate the proportion or percentage of companies that have the specific characteristic. Such are the cases of the Owner/manager (OS1), Partner/manager (OS2), Outside/manager (OS3) and State (ST) variables. Our results indicate that $21.52 \%$ of the companies are managed by a manager who is also the total owner of the company (OS1), $36.35 \%$ of the companies are managed by a manager who is a partial owner of the company (OS2) and whose average ownership is $41.32 \%$ (MO), $42.13 \%$ of the companies are managed by an external manager who does not have ownership in the company (OS3). Finally, we note that $1.61 \%$ of companies have a State (ST) presence in their ownership structure, with an average state ownership (SO) of $1.43 \%$.

Other firm qualities show that the growth opportunities (GO) are equivalent to an annual sales growth of $16.39 \%$, while the average debt-to-equity ratio (LEV) is 2.23, which marks the primary use of debt as funding source. The operational expense to sales 
ratio that quantifies the agency costs $(\mathrm{AC})$ is on average $18.45 \%$, while the average firms profitability (FP) is $11.80 \%$. It should be noted that $24.04 \%$ of the companies belong to business holdings (HD).

Table 2. Statistical summary.

\begin{tabular}{|c|c|c|c|c|}
\hline \multirow{2}{*}{ Variable } & \multicolumn{4}{|c|}{ Full sample } \\
\hline & Mean & S.D. & Min. & Max. \\
\hline \multicolumn{5}{|l|}{ Dependent variable } \\
\hline Debt maturity ( $\%$ ) & 19.02 & 29.05 & 0 & 1 \\
\hline \multicolumn{5}{|l|}{ Ownership structure } \\
\hline Owner/manager ( \%) & 21.52 & 40.61 & 0 & 1 \\
\hline Partner/manager ( \%) & 36.35 & 47.95 & 0 & 1 \\
\hline Managerial ownership (\%) & 41.32 & 34.03 & 0.02 & 0.95 \\
\hline Outside/manager ( $\%)$ & 42.13 & 48.12 & 0 & 1 \\
\hline State $(\%)$ & 1.61 & 7.65 & 0 & 1 \\
\hline State ownership (\%) & 1.43 & 6.07 & 0 & 1 \\
\hline \multicolumn{5}{|l|}{ Growth opportunities } \\
\hline Growth in sales (\%) & 16.39 & 32.13 & -4.32 & 28.45 \\
\hline \multicolumn{5}{|l|}{ Capital structure } \\
\hline Corporate debt & 2.23 & 2.72 & 0 & 13.73 \\
\hline \multicolumn{5}{|l|}{ Other control variables } \\
\hline Agency costs (\%) & 18.45 & 18.99 & 0 & 36.94 \\
\hline Firm profitability ( \%) & 11.8 & 11.6 & -18.46 & 37.32 \\
\hline External monitoring (years) & 15 & 12.06 & 0 & 76 \\
\hline Firm quality (level) & 4.99 & 4.16 & -4.95 & 19.75 \\
\hline Firm size (Bill. \$) & 129.21 & 621 & 0.001 & 783.96 \\
\hline Holding $(\%)$ & 24.04 & 41.86 & 0 & 1 \\
\hline Tangibility ( \%) & 28.92 & 30.07 & 5.49 & 97.47 \\
\hline
\end{tabular}

Table 3 indicates the statistical summary of the company sample by survey. It is important to mention that the LBS sample design shows the growing participation of large companies from the first to the fourth version of the survey. This fact explains some statistical results, mainly for ownership structure, financing and firm size.

The statistical results for ownership structure indicate that managerial participation in ownership structure goes from $52.58 \%$ in LBS1 to $26.47 \%$ in LBS4. This fact shows that ownership structures are more diluted towards LBS4, which is related to a greater presence of large companies. In line with the above, the firms managed by an external manager increased from $27.23 \%$ in LBS1 to $57.80 \%$ in LBS4, while firms managed by their owner declined from $35.71 \%$ to $12.51 \%$ for the same surveys. Firms managed by a partner/manager had showed more stable behavior in relation to other managerial roles. State ownership in companies was comparatively small. Firms with State presence in their ownership structure fluctuated between $1.28 \%$ and $1.85 \%$, with an average participation no greater than $1.55 \%$. Although State presence in Chilean firms is small, its corporate and institutional effects are empirically relevant. More diluted ownership structures are consistent with the higher agency costs described in the sample.

Firm capital structure shows the significant presence of debt in corporate financing. The debt-to-equity ratio went from 1.45 in the LBS1 to 3.88 in the LBS4, an increase from $59.18 \%$ to $74.22 \%$ if debt is measured in relation to total assets. This was accompanied by 
REMEF (The Mexican Journal of Economics and Finance)

a greater use of long-term debt, which increased by $6.09 \%$ in the LBS 4 with respect to the LBS1 and an increasingly extensive relationship with external financiers. The proportion of long-term assets increased by approximately $6.59 \%$ in the same period, which supports the finding that companies match the maturity of their liabilities with that of their assets. Despite the growing use of long-term debt shown in LBS4, short-term debt had a greater presence in corporate debt composition.

Table 3. Statistical summary by survey/year.

\begin{tabular}{|c|c|c|c|c|c|c|c|c|}
\hline \multirow{2}{*}{ Variable } & \multicolumn{2}{|c|}{2007} & \multicolumn{2}{|c|}{2009} & \multicolumn{2}{|c|}{2013} & \multicolumn{2}{|c|}{2015} \\
\hline & Mean & S.D. & Mean & S.D. & Mean & S.D. & Mean & S.D. \\
\hline \multicolumn{9}{|l|}{ Dependent variable } \\
\hline Debt maturity (\%) & 16.63 & 28.81 & 17.01 & 28.16 & 19.72 & 28.96 & 22.72 & 30.25 \\
\hline \multicolumn{9}{|l|}{ Ownership structure } \\
\hline Owner/manager (\%) & 35.71 & 49.6 & 21.64 & 41.21 & 18.15 & 38.54 & 12.51 & 33.09 \\
\hline Partner/manager (\%) & 38.04 & 48.66 & 41.05 & 49.29 & 36.63 & 48.18 & 29.67 & 45.68 \\
\hline Managerial ownership (\%) & 52.58 & 28.29 & 50.8 & 27.94 & 35.45 & 41.43 & 26.47 & 38.46 \\
\hline Outside/manager ( $\%)$ & 27.23 & 45.85 & 38.29 & 47.47 & 45.19 & 49.77 & 57.8 & 49.39 \\
\hline State $(\%)$ & 1.7 & 8.37 & 1.59 & 7.69 & 1.85 & 9.2 & 1.28 & 5.32 \\
\hline State ownership (\%) & 1.49 & 6.35 & 1.43 & 6.15 & 1.55 & 7.01 & 1.23 & 4.78 \\
\hline \multicolumn{9}{|l|}{ Growth opportunities } \\
\hline Growth in sales (\%) & 22.83 & 30.68 & 14.9 & 33.86 & 16.78 & 31.49 & 11.06 & 32.47 \\
\hline \multicolumn{9}{|l|}{ Capital structure } \\
\hline Corporate debt & 1.45 & 2.14 & 1.52 & 2.13 & 2.09 & 2.56 & 3.88 & 4.06 \\
\hline \multicolumn{9}{|l|}{ Other control variables } \\
\hline Agency costs (\%) & 11.38 & 15.74 & 24.5 & 21.12 & 17.75 & 18.3 & 20.15 & 20.81 \\
\hline Firm profitability ( \%) & 13.15 & 21.11 & 11.91 & 8.18 & 9.29 & 10.4 & 12.86 & 6.71 \\
\hline External monitoring (years) & 12.82 & 12.54 & 12.65 & 10.16 & 16.34 & 11.56 & 18.17 & 13.98 \\
\hline Firm quality (level) & 5.74 & 5.21 & 3.59 & 3.25 & 3.74 & 4.19 & 6.9 & 3.97 \\
\hline Firm size (Bill. $\$$ ) & 20.44 & 338.4 & 150.15 & 816.12 & 168.4 & 683.46 & 177.83 & 646.02 \\
\hline Holding ( $\%)$ & 13.57 & 34.25 & 21.52 & 41.1 & 29.37 & 45.55 & 31.69 & 46.53 \\
\hline Tangibility (\%) & 28.56 & 27.62 & 29.31 & 26.67 & 22.65 & 26.05 & 35.15 & 39.94 \\
\hline
\end{tabular}

Firm growth opportunities declined through the surveys. The annual growth of sales fell from $22.83 \%$ in the LBS1 to $11.06 \%$ in the LBS4. Along the same line, firm profitability also fell, although to a lesser extent. In spite of the above, firms credit quality in the sample showed a low probability of bankruptcy.

Finally, we highlighted that the proportion of companies belonging to corporate holdings increased from $13.57 \%$ in the LBS1 to $31.69 \%$ in the LBS4. This fact is in line with the greater presence of large companies in the sample.

\subsection{Non-linear effects of ownership structure, growth opportuni- ties and leverage}

Model (3) results are presented in Table 4 (marginal effects). The Tobit model includes dummy variables in order to capture systematic differences according to different economic sectors and years. Wald is a chi-square test that under the null hypothesis supports the non-statistical relevance of all model parameters. In all cases, this test is rejected, a result that supports the global significance of all estimated models.

Control variables such as firm credit quality (FQ), firm profitability (FP), external monitoring (EM) and belonging to a business holding (HD) have a negative and significant effect on debt maturity. Thus, profitable firms with higher credit quality, with a more extensive relationship with their financiers and that its part of business conglomerates prefer short-term debt. Agency costs (AC) have a negative effect, but not significant. 
Revista Mexicana de Economía y Finanzas Nueva Época, Vol. 14 No. 1, (2019), pp. 21-40 DOI: http://dx.doi.org/10.21919/remef.v14i1.357

Control variables have the expected effects, as proposed by international studies (Flannery, 1986; Barclay and Smith, 1995; Lasfer, 1999). On the other hand, firm size (SIZE) and asset tangibility (TANG) have a positive and significant effect (Arslan and Karan, 2006; Benmelech, 2006; Alcock et al., 2012; Muñoz and Sepúlveda, 2016).

Ownership structure has significant effects on the debt maturity of Chilean companies. Debt maturity is significantly reduced when the firm is managed by owner/manager (OS1) and increased if the company is managed by a partner/manager (OS2) or an outside manager (OS3). This result partially supports the idea that debt maturity reductions, caused by ownership concentration, align managerial interests with that of firm owners. The longer debt terms observed when the ownership is diluted is a reflection of the manager's intention to avoid external supervision. Along the same line, managerial ownership (MO) has a positive and non-linear effect on debt maturity. This result corroborates hypothesis H1. Nonlinearity indicates that, when the managerial ownership is low, debt maturity increases significantly. This result is consistent with the managerial entrenchment hypothesis (Berger et al., 1997; Gompers et al., 2003; Datta et al., 2005; Arslan and Karan, 2006; Benmelech, 2006; Harford et al., 2008). However, when the managerial ownership exceeds $58.74 \%$, the effect is reversed, causing a reduction in debt terms, which supports the debt control hypothesis (Ozkan, 2000; Guney and Ozkan, 2005; García and Martínez, 2010). In addition, the positive effect of the MO variable is due to the fact that managerial ownership, which on average is $41.32 \%$, is below the inflection level.

State ownership (SO) also has a positive and significant effect on debt maturity, supporting hypothesis H2. State ownership allows companies to access long-term debt, and most likely with less collateral requirements. This result is consistent with the findings of Choi (2015) and Boubakri and Saffar (2017). However, the non-monotonicity of the SO variable suggests that the positive impact only exists when state ownership levels are less than $47 \%$.

Growth opportunities (GO), measured through the annual sales growth, points to a negative effect on debt maturity. This effect is significant at $1 \%$ and is in line with several international studies (Myers, 1977; Titman, 1992; Barclay and Smith, 1995; Ozkan, 2000; Johnson, 2003; Arslan and Karan, 2006; García and Martínez, 2010). Results show that greater growth opportunities open spaces to allow the manager-shareholder block to develop underinvestment practices, through which creditors are expropriated from wealth them. To mitigate the cost of underinvestment, companies shorten debt maturity to impose a more rigorous supervision on company management. In addition, growth opportunities effect is non-linear, validating hypothesis H3. Non-linearity suggests that this effect is not persistent. When annual sales growth exceeds $21.82 \%$, growth opportunities positively affect debt maturity. This second effect reveals that long-term debt limits managerial discretion in relation to investment policy and promotes the mitigation of liquidity risk.

Corporate debt level (LEV) has a positive and significant effect on debt maturity. According to several empirical studies, this result reveals that Chilean firms prefer to mitigate bankruptcy and liquidity risks when issuing debt (Diamond, 1991; Morris, 1992; Leland and Toft, 1996; Datta et al., 2005; Dang, 2011). In addition, the effect of debt on maturity is non-linear, a result which favors hypothesis H4. Non-linearity observed for the effect of debt level on debt maturity has two implications. First, this non-linear relationship has an inverted U-shape. Alcock et al. (2011) stated that the relationship between leverage and maturity has this shape if the debt issued uses restrictive covenants in contracts. This fact guides the trade-off between overinvestment risk and bankruptcy risk towards minimization of debt costs, through more restrictive covenants. Second, given the form of the non-linear relationship, when the debt to equity ratio is greater than 8.61 , the effect of debt level on debt maturity becomes negative. In this way, when debt level is high, reduction in debt maturity becomes a means of effectively controlling the overinvestment problem (Barclay et al., 2003). On the contrary, the positive impact of 
REMEF (The Mexican Journal of Economics and Finance)

leverage on debt terms is explained because the magnitude of debt of Chilean companies averages 2.23 , which is clearly lower than the critical level.

Table 4. Tobit regression for debt maturity in Chilean firms, marginal effects.

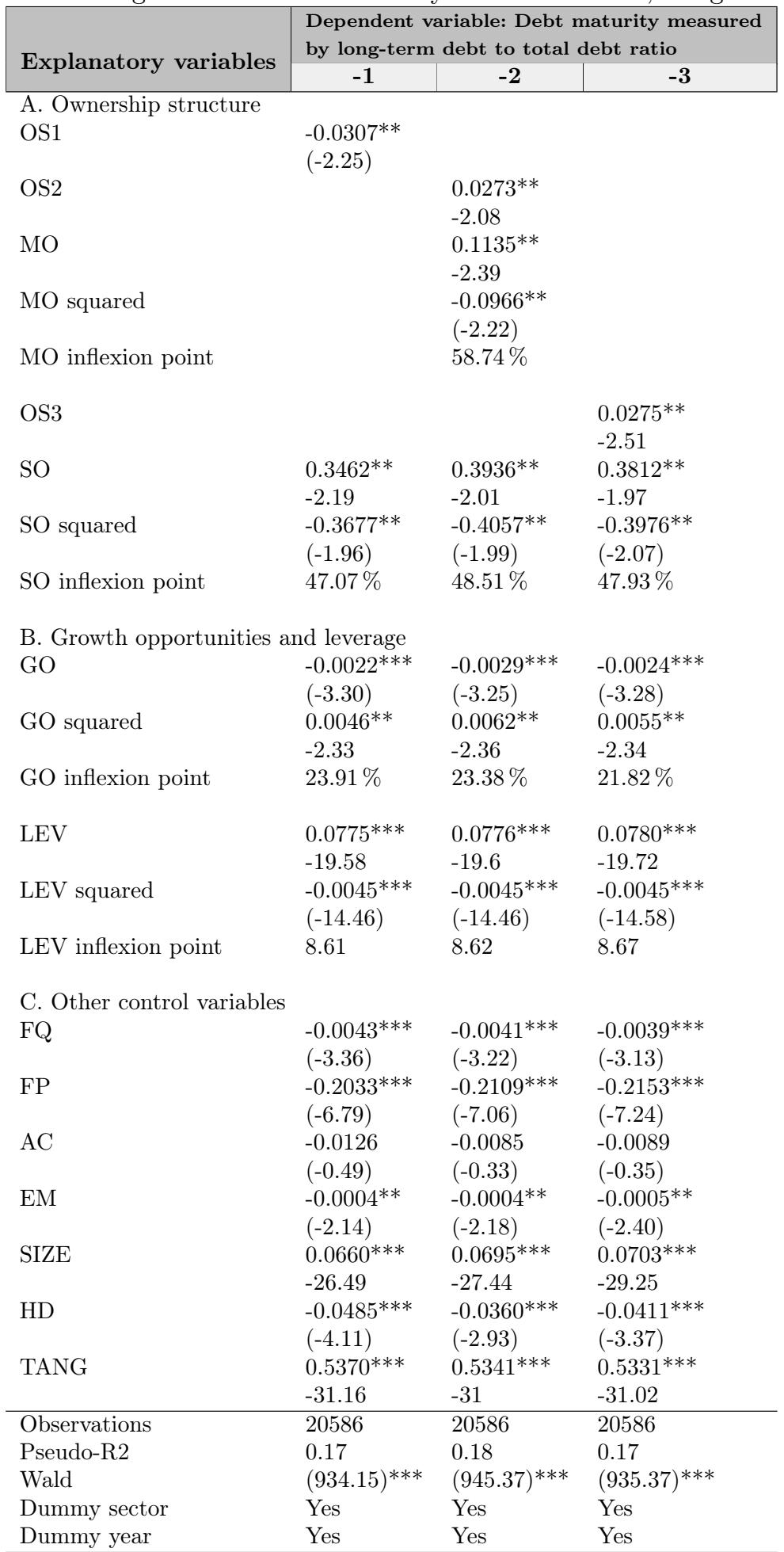

Marginal effects. Z-statistics in bracket. Superscripts ***, **, * indicate statistical significance at 1, 5, and 10 percent, respectively. Source: Own elaboration. 
Table 5 shows model (4) results. Variables such as firm credit quality (FQ), firm profitability (FP), external monitoring (EM) and belonging to a business holding (HD) have a negative effect, similar to that observed in Table 4. Firm size (SIZE) and asset tangibility (TANG) have a positive effect. Agency costs (AC) have no effect on debt maturity. Ownership structure (OS), managerial ownership (MO), State ownership (SO) and growth opportunities (GO) also presented similar results to those described in Table 4.

Table 5. Tobit regression for debt maturity in Chilean firms, marginal effects.

\begin{tabular}{|c|c|c|c|c|c|c|}
\hline \multirow{2}{*}{ Explanatory variables } & \multicolumn{6}{|c|}{$\begin{array}{l}\text { Dependent variable: Debt maturity measured } \\
\text { by the long-term debt to total debt ratio }\end{array}$} \\
\hline & -1 & -2 & -3 & -4 & -5 & -6 \\
\hline \multicolumn{7}{|l|}{ A. Ownership structure } \\
\hline OS1 & $\begin{array}{c}-0.0351^{* *} \\
(-2.55)\end{array}$ & & & $\begin{array}{c}-0.0351^{* *} \\
(-2.55)\end{array}$ & & \\
\hline OS2 & & $\begin{array}{l}0.0245^{* *} \\
-1.99\end{array}$ & & & $\begin{array}{l}0.0245^{* *} \\
-1.99\end{array}$ & \\
\hline MO & & $\begin{array}{l}0.1437^{* * *} \\
-2.75\end{array}$ & & & $\begin{array}{l}0.1437^{* * *} \\
-2.75\end{array}$ & \\
\hline MO squared & & $\begin{array}{c}-0.1090^{* * *} \\
(-2.63)\end{array}$ & & & $\begin{array}{c}-0.1090^{* * *} \\
(-2.63)\end{array}$ & \\
\hline OS3 & & & $\begin{array}{l}0.0276^{* *} \\
-2.5\end{array}$ & & & $\begin{array}{l}0.0276^{* *} \\
-2.5\end{array}$ \\
\hline SO & $\begin{array}{c}0.3439^{*} \\
-1.87\end{array}$ & $\begin{array}{c}0.3936^{* *} \\
-2\end{array}$ & $\begin{array}{l}0.3808^{* *} \\
-1.97\end{array}$ & $\begin{array}{c}0.3439^{*} \\
-1.87\end{array}$ & $\begin{array}{l}0.3936^{* *} \\
-2\end{array}$ & $\begin{array}{l}0.3808^{* *} \\
-1.97\end{array}$ \\
\hline SO squared & $\begin{array}{c}-0.3635^{*} \\
(-1.78)\end{array}$ & $\begin{array}{c}-0.4035^{*} \\
(-1.91)\end{array}$ & $\begin{array}{c}-0.3953^{* *} \\
(-2.46)\end{array}$ & $\begin{array}{c}-0.3635^{*} \\
(-1.78)\end{array}$ & $\begin{array}{c}-0.4035^{*} \\
(-1.91)\end{array}$ & $\begin{array}{c}-0.3953^{* *} \\
(-2.46)\end{array}$ \\
\hline \multicolumn{7}{|c|}{ B. Growth opportunities and leverage } \\
\hline GO & $\begin{array}{l}-0.0031^{* * *} \\
(-2.97)\end{array}$ & $\begin{array}{l}-0.0029^{* * *} \\
(-2.94)\end{array}$ & $\begin{array}{l}-0.0034^{* * *} \\
(-2.97)\end{array}$ & $\begin{array}{c}-0.0031^{* * *} \\
(-2.97)\end{array}$ & $\begin{array}{c}-0.0029^{* * *} \\
(-2.94)\end{array}$ & $\begin{array}{l}-0.0034^{* * *} \\
(-2.97)\end{array}$ \\
\hline LEV & $\begin{array}{c}0.0136^{* * *} \\
-4.67\end{array}$ & $\begin{array}{c}0.0135^{* * *} \\
-4.64\end{array}$ & $\begin{array}{c}0.0131^{* * *} \\
-4.51\end{array}$ & $\begin{array}{c}0.0277^{\text {*** }} \\
-14.73\end{array}$ & $\begin{array}{c}0.0279^{* * *} \\
-14.83\end{array}$ & $\begin{array}{c}0.0280^{* * *} \\
-14.92\end{array}$ \\
\hline LEV DSmall & $\begin{array}{c}0.0141^{* * *} \\
-4.33\end{array}$ & $\begin{array}{c}0.0144^{* * *} \\
-4.41\end{array}$ & $\begin{array}{c}0.0149^{* * *} \\
-4.6\end{array}$ & & & \\
\hline LEV DLarge & & & & $\begin{array}{c}-0.0141^{* * *} \\
(-4.33)\end{array}$ & $\begin{array}{c}-0.0144^{* * *} \\
(-4.41)\end{array}$ & $\begin{array}{c}-0.0149^{* * *} \\
(-4.60)\end{array}$ \\
\hline LEVDHG & $\begin{array}{c}-0.0082 \\
(-0.98)\end{array}$ & $\begin{array}{c}-0.0082 \\
(-0.98)\end{array}$ & $\begin{array}{c}-0.0082 \\
(-0.97)\end{array}$ & $\begin{array}{c}-0.0274^{* * *} \\
(-13.63)\end{array}$ & $\begin{array}{c}-0.0275^{* * *} \\
(-13.72)\end{array}$ & $\begin{array}{c}-0.0277^{* * *} \\
(-13.80)\end{array}$ \\
\hline LEV DHG DSmall & $\begin{array}{c}-0.0191^{* *} \\
(-2.21)\end{array}$ & $\begin{array}{c}-0.0193^{* *} \\
(-2.22)\end{array}$ & $\begin{array}{c}-0.0195^{* *} \\
(-2.24)\end{array}$ & & & \\
\hline LEV DHG DLarge & & & & $\begin{array}{c}0.0191^{* *} \\
-2.21\end{array}$ & $\begin{array}{c}0.0193^{* *} \\
-2.22\end{array}$ & $\begin{array}{c}0.0195^{* * *} \\
-2.24\end{array}$ \\
\hline \multicolumn{7}{|l|}{ C. Other control variables } \\
\hline FQ & $\begin{array}{c}-0.0039^{* * *} \\
(-3.11)\end{array}$ & $\begin{array}{c}-0.0038^{* * *} \\
(-2.96)\end{array}$ & $\begin{array}{c}-0.0036^{* * *} \\
(-2.86)\end{array}$ & $\begin{array}{c}-0.0039^{* * *} \\
(-3.11)\end{array}$ & $\begin{array}{c}-0.0038^{* * *} \\
(-2.96)\end{array}$ & $\begin{array}{c}-0.0036^{* * *} \\
(-2.86)\end{array}$ \\
\hline FP & $\begin{array}{c}-0.2165^{* * *} \\
(-7.20)\end{array}$ & $\begin{array}{c}-0.2246^{* * *} \\
(-7.48)\end{array}$ & $\begin{array}{c}-0.2297^{* * *} \\
(-7.69)\end{array}$ & $\begin{array}{c}-0.2165^{* * *} \\
(-7.20)\end{array}$ & $\begin{array}{c}-0.2246^{* * *} \\
(-7.48)\end{array}$ & $\begin{array}{c}-0.2297^{* * *} \\
(-7.69)\end{array}$ \\
\hline $\mathrm{AC}$ & $\begin{array}{c}-0.0168 \\
(-0.65)\end{array}$ & $\begin{array}{c}-0.0123 \\
(-0.47)\end{array}$ & $\begin{array}{c}-0.0126 \\
(-0.49)\end{array}$ & $\begin{array}{c}-0.0168 \\
(-0.65)\end{array}$ & $\begin{array}{c}-0.0123 \\
(-0.47)\end{array}$ & $\begin{array}{c}-0.0126 \\
(-0.49)\end{array}$ \\
\hline EM & $\begin{array}{c}-0.0009^{* * *} \\
(-2.64)\end{array}$ & $\begin{array}{c}-0.0010^{* * *} \\
(-2.69)\end{array}$ & $\begin{array}{c}-0.0011^{* * *} \\
(-2.96)\end{array}$ & $\begin{array}{c}-0.0009^{* * *} \\
(-2.64)\end{array}$ & $\begin{array}{c}-0.0010^{* * *} \\
(-2.69)\end{array}$ & $\begin{array}{c}-0.0011^{* * *} \\
(-2.96)\end{array}$ \\
\hline SIZE & $\begin{array}{c}0.0716^{* * *} \\
-27.37\end{array}$ & $\begin{array}{c}0.0754^{* * *} \\
-28.42\end{array}$ & $\begin{array}{c}0.0764^{* * *} \\
-30.53\end{array}$ & $\begin{array}{c}0.0716^{* * *} \\
-27.37\end{array}$ & $\begin{array}{c}0.0754^{* * *} \\
-28.42\end{array}$ & $\begin{array}{c}0.0764^{* * * *} \\
-30.53\end{array}$ \\
\hline HD & $\begin{array}{c}-0.0430 \text { *** } \\
(-3.62)\end{array}$ & $\begin{array}{c}-0.0301^{* *} \\
(-2.43)\end{array}$ & $\begin{array}{c}-0.0355^{* * *} \\
(-2.89)\end{array}$ & $\begin{array}{c}-0.0430^{* * *} \\
(-3.62)\end{array}$ & $\begin{array}{c}-0.0301^{* *} \\
(-2.43)\end{array}$ & $\begin{array}{c}-0.0355^{* * *} \\
(-2.89)\end{array}$ \\
\hline TANG & $\begin{array}{c}0.5365^{* * *} \\
-30.93\end{array}$ & $\begin{array}{c}0.5334^{* * *} \\
-30.76\end{array}$ & $\begin{array}{c}0.5321^{* * *} \\
-30.77\end{array}$ & $\begin{array}{c}0.5365^{* * *} \\
-30.93\end{array}$ & $\begin{array}{c}0.5334^{* * *} \\
-30.76\end{array}$ & $\begin{array}{c}0.5321^{* * *} \\
-30.77\end{array}$ \\
\hline Observations & 20586 & 20586 & 20586 & 20586 & 20586 & 20586 \\
\hline Pseudo-R2 & 0.16 & 0.17 & 0.16 & 0.16 & 0.17 & 0.16 \\
\hline Wald & $(698.07)^{* * *}$ & $(710.18)^{* * *}$ & $(697.80)^{* * *}$ & $(698.07)^{* * *}$ & $(710.18)^{* * *}$ & $(697.80)^{* * *}$ \\
\hline Dummy sector & Yes & Yes & Yes & Yes & Yes & Yes \\
\hline Dummy year & Yes & Yes & Yes & Yes & Yes & Yes \\
\hline
\end{tabular}


REMEF (The Mexican Journal of Economics and Finance)

Non-linear Effects of Ownership Structure, Growth Opportunities

Corporate debt (LEV) has a positive impact on debt maturity, according to mitigating bankruptcy risk. However, the effect of debt level on debt maturity varies according to firm size. The dummy variable DSIZE, indicated in section 3.2, was defined simultaneously for both small (DSmall) and large (DLarge) firms. The iterative variable LEVDSmall has a positive and significant effect on debt maturity, while LEVDLarge has a negative impact, which supports hypothesis H5. Thus, when small firms take out loans, they prefer to do so in the long term, as to mitigate bankruptcy and liquidity risks, while large firms prefer short-term debt as a way of controlling overinvestment. This difference is explained by the differences in debt levels of these types of firms. According to sample data, small firms have an average debt to equity ratio of 1.04, while large firms have a debt to equity ratio of 9.73. If we consider the concavity of the relationship between leverage and debt maturity and that the critical inflection value is equivalent to a debt to equity ratio of 8.61 , small firms are located below this value and large firms above it. In line with Dang (2011), we formulated the iterative variables LEVDHGDSmall and LEVDHGDlarge in order to examine the relationship between leverage and debt maturity when small and large companies face high growth opportunities. Results show that high growth opportunities reverse the previous results. Thus, for small firms, their preference to mitigate bankruptcy and liquidity risks is diluted and inclined to controlling underinvestment risks when they have high growth opportunities. In large firms, the change is in favor of controlling the long-term discretion of the administration.

\section{Conclusions and discussion}

Debt maturity is a subject that has been investigated extensively during the last few decades. Different fields of analysis have placed it as a means of controlling various types of costs within companies, affecting their market value.

Our investigation resulted in findings that agree with those of previous studies. On one hand, variables such as firm credit quality, profitability, external monitoring and belonging to business holding has a negative impact on debt maturity. On the other hand, firm size and asset tangibility has the expected positive effect. Our results show that Chilean companies that expand into long-term assets match the maturity of their investments with that of their debts, although short-term debt replaces external monitoring, which is associated with larger, more profitable companies and with higher credit quality.

According to the objectives of our research, we can summarize the implications of the results in three points. First, ownership structure has significant effects on debt maturity. Managerial ownership has a positive effect on debt maturity, which is consistent with the managerial entrenchment hypothesis. This effect is observed for low levels of managerial ownership and that does not exceed $58.74 \%$. On average, managers own $41.32 \%$ of the ownership of the Chilean companies included in the sample, a magnitude lower than the level described. This result is relevant for the Chilean market and mainly for bondholders and banks, who exercise external control role over these companies. Such control becomes less rigorous when managers issue long-term debt to isolate themselves from supervision. This entrenchment may be conducive to discretionary decisions taken by managers to expropriate wealth from the owners. However, non-linearity suggests that, in companies where managerial ownership exceeds $58.74 \%$, debt maturity is reduced. This effect replaces the corporate control role associated with the ownership concentration and mitigates agency costs associated with managerial discretion and entrenchment. The form of nonlinearity indicates that Chilean companies consider minimizing the cost of debt in their financing policy.

State ownership has a positive effect on debt maturity. Scarce international evidence in this matter attributes this result to the fact that the State represents a means of financial support against a possible breach of the debt contract. This role of the State makes creditor demands more flexible in terms of debt costs and guarantee requirements. 
However, in Chile, State participation in firm ownership is low in relation to other countries with similar structural characteristics. This context makes the role of the State as guarantor very broad for Chilean companies. In fact, the positive relationship between State ownership and debt maturity was observed in companies where State presence did not exceed $47.07 \%$ ownership. If we consider that $1.61 \%$ of the companies in the sample had a State presence in their ownership structure and that the average State participation in these companies was $1.43 \%$, we concluded that the positive effect of State ownership on the debt maturity is relevant.

Second, growth opportunities have a negative and non-linear impact on debt maturity, supporting the existence of a trade-off between underinvestment costs and bankruptcy risk. When the annual growth of sales is less than $21.82 \%$, the relationship between growth opportunities and debt maturity is negative. This result suggests that for those levels of sales growth, firms use short-term debt to mitigate underinvestment costs and to discipline managers. For annual sales growth above that level, the preference for mitigating liquidity and bankruptcy risk lead firms to issue long-term debt. This finding is of empirical and practical relevance for creditors in Chile. The possibility of identifying firms according to their growth opportunities allows investors to make an adequate debt term decision in order to manage the expropriation of risks inherent to firms that underinvest.

Third, leverage is also relevant to the debt maturity decision. Our results indicate that the debt level of Chilean companies has, on average, a positive effect on debt term decisions, therefore helping to mitigate the bankruptcy risk. In addition, this relationship is found to be non-linear and has an inverted U-shape, thus showing that Chilean firms issue debt based on costly contracting which reduces the risk of creditors. As a result, the control of liquidity and bankruptcy risks are observable until a debt to equity ratio of 8.61. The negative relationship between leverage and debt maturity is consistent with the overinvestment cost hypothesis. In any case, this trade-off differs according to firm size. In small firms, this trade-off favors long-term debt, while in large firms it encourages a reduction in debt maturity.

Our results contribute to the empirical evidence in the aspects described. However, the impossibility of identifying firms through different surveys prevents the structuring of the data as a panel and estimating the possible and unobservable firm qualities that could affect debt maturity. Finally, we considered that debt maturity in Chilean companies is a topic that has yet to be fully explored. Future studies should delve into the effect of corporate governance practices on debt term length. This topic is of interest given Chile's entry into the OECD and the recommendations that this body has imposed on business management practices and other matters in Chile.

\section{References}

Aivazian, V., Y. Ge, and J. Qiu (2005). Debt Maturity Structure and Firm Investment. Financial Management, 34(4), pp. 107-119.

Alcock, J., F. Finn, and K. Keng (2011). Debt Covenants, Agency Costs and Debt Maturity. Working paper, The University of Queensland, Brisbane, 4072, Australia.

Alcock, J., F. Finn, and K. Keng (2012). The Determinants of Debt Maturity in Australian Firms. Accounting and Finance, 52(2), pp. 313-341.

Amemiya, T. (1984). Tobit models: A survey. Journal of Econometrics. 24 (1-2), pp. 3-61.

Amemiya, T. (1985). Tobit Models. Advanced Econometrics. Oxford: Basil Blackwell. pp. 360-411.

Ang, J., R. Cole, and J. Lin (2000). Agency Costs and Ownership Structure. Journal of Finance, 55(1), pp. 81-106.

Antoniou, A., Y. Guney, and K. Paudyal. (2006). The Determinants of Debt Maturity Structure: Evidence from France, Germany and the UK. European Financial Management, 12(2), pp. 161-194. 
REMEF (The Mexican Journal of Economics and Finance)

Arslan, O., and M. Karan (2006). Ownership and Control Structure as Determinants of Corporate Debt Maturity: A panel study of an Emerging Market. Corporate Governance: An International Review, 14(4), pp. 312-324.

Azofra, V., P. Saona, and E. Vallelado (2004). Estructura de Propiedad y Oportunidades de Crecimiento como determinantes del Endeudamiento de las Empresas Chilenas. Revista Abante, 7(2), pp. 105145 .

Barclay, M., L. Marx, and C. Smith (2003). The Joint Determination of Leverage and Maturity. Journal of Corporate Finance, 9(2), pp. 149-167.

Barclay, M., and C. Smith (1995). The Maturity Structure of Corporate Debt. The Journal of Finance, 50(2), pp. 609-631.

Barclay, M., and C. Smith (1996). On Financial Architecture: Leverage, Maturity, and Priority. Journal of Applied Corporate Finance, 8(4), pp. 4-17.

Barnea, A., R. Haugen, and L. Senbet (1980). A Rationale for Debt Maturity Structure and Call Provisions in the Agency Theoretic Framework. Journal of Finance, 35(5), pp. 1223-1234

Benmelech, E. (2006). Managerial Entrenchment and Debt Maturity: Theory and Evidence. Working paper, Harvard University.

Berger, P., E. Ofek, and D. Yermack (1997). Managerial Entrenchment and Capital Structure Decisions. The Journal of Finance, 52(4), pp. 1411-1438.

Billet, M., T. King, and D. Mauer (2007). Growth Opportunities and the Choice of Leverage, Debt Maturity and Covenants. The Journal of Finance, 62(2), pp. 696-730.

Borisova, G., P. Brockman, J. Salas, and A. Zagorchev (2012). Government Ownership and Corporate Governance: Evidence from the EU. Journal of Banking and Finance, 36(11), pp. 2917-2934.

Borisova, G., V. Fotak, K. Holland, and W. Megginson (2015). Government Ownership and the Cost of Debt: Evidence from Government Investments in Publicly Traded Firms. Journal of Financial Economics, 118(1), pp. 168-191.

Borisova, G., and W. Megginson. (2011). Does Government Ownership affect the Cost of Debt? Evidence from Privatization. Review of Financial Studies, 24(8), pp. 2693-2737.

Boubakri, N., and W. Saffar (2017). State Ownership and Debt Choice: Evidence from Privatization. Working paper, March 2017.

Castañeda, F., and F. Contreras (2017). The Determinants of Corporate Debt Maturity Structure: The case of Chile. El Trimestre Económico, 84(2), pp. 411-425.

Chang, K., J. Wee, and H. Yi (2011). Does National Culture Influence the Firm's Choice of Debt Maturity?, Working paper.

Childs, P., D. Mauer, and S. Ott (2005). Interactions of Corporate Financing and Investment Decisions: The Effects of Agency Conflicts. Journal of Financial Economics, 76(3), pp. 667-690.

Choi, Y. (2015). Managerial Stock Ownership and Debt Maturity: Evidence from Chinese Firms. Journal of the Korea Convergence Society, 6(1), pp.71-76.

Danbolt, J., I. Hirst, and E. Jones (2011). The Growth Companies Puzzle: Can Growth Opportunities measures predict Firm Growth?. European Journal of Finance, 17(1), pp. 1-25.

Dang, V. (2011). Leverage, Debt Maturity and Firm Investment: An Empirical Analysis. Journal of Business Finance and Accounting, 38(1) (2), pp. 225-258.

Datta, S., M. Iskandar-Datta, and K. Raman (2005). Managerial Stock Ownership and the Maturity Structure of Corporate Debt. Journal of Finance, 60(5), pp. 2300-2350.

De Angelo, H., L. De Angelo, and K. Wruck (2002). Asset Liquidity, Debt Covenants and Managerial Discretion in Financial Distress: The collapse of L.A. Gear. Journal of Financial Economics, 64(1), pp. 3-34.

Demirguc-Kunt, A., and V. Maksimovic (1999). Institutions, Financial Markets and Firm Debt Maturity. Journal of Financial Economics, 54(3), pp. 295-336.

Diamond, D. (1991). Debt Maturity Structure and Liquidity Risk. The Quarterly Journal of Economics, 106(3), pp. 709-737.

Domenichelli, O. (2015). An Empirical Investigation of the Debt Maturity of Italian Family Firms. International Journal of Finance and Accounting, 4(5), pp. 281-292.

Fan, J., S. Titman, and G. Twite (2010). An International Comparison of Capital Structure and Debt Maturity Choices. NBER, Working Paper 16445.

Flannery, M. (1986). Asymmetric Information and Risky Debt Maturity Choice. Journal of Finance, 41(1), pp. 19-37.

Fleming, G., R. Heaney, and R. McCosker (2005). Agency Costs and Ownership Structure in Australia. Pacific-Basin Finance Journal, 13(1), pp. 29-52.

García-Teruel, P., and P. Martínez-Solano (2010). Ownership Structure and Debt Maturity: New evidence from Spain. Review of Quantitative Finance and Accounting, 35(4), pp. 473-491.

Gompers, P., J. Ishii, and A. Metrick (2003). Corporate Governance and Equity Prices. Quarterly Journal of Economics, 118(1), pp: 107-155.

Guedes, J., and T. Opler (1996). The Determinants of the Maturity of Corporate Debt Issue. Journal of Finance, 51(5), pp. 1809-1833. 
Revista Mexicana de Economía y Finanzas Nueva Época, Vol. 14 No. 1, (2019), pp. 21-40

DOI: http://dx.doi.org/10.21919/remef.v14i1.357

Guney, Y., and A. Ozkan (2005). New Insights on the Importance of Agency Costs for Corporate Debt Maturity Decisions. Applied Financial Economics Letters, 1(4), pp. 233-238.

Hackethal, A., and C. Jansen (2006). New Empirical Evidence on the Debt Maturity Choice and the Role of Credit Risk. Working paper, December 2006.

Harford, J., K. Li, and X. Zhao (2008). Corporate Boards and the Leverage and Debt Maturity Choices. International Journal of Corporate Governance, 1(1), pp. 3-27.

Harris, M., and A. Raviv (1991). The Theory of Capital Structure. Journal of Finance, 46(1), pp. 297-355.

Hart, O., and J. Moore (1995). Debt Seniority: An Analysis of the Role of Hard Claims on Constraining Management. American Economic Review, 85(3), pp. 567-585.

Jensen, M., (1986). Agency Costs of Free Cash Flow, Corporate Finance and Takeovers. American Economic Review, 76(2), pp. 323-329.

Jensen, M., and W. Meckling (1976). Theory of the Firm: Managerial Behavior, Agency Costs and Capital Structure. Journal of Financial Economics, 3(4), pp. 305-360.

Jiraporn, P., and S. Tong (2008). Debt Maturity Structure, Agency Costs and Firm Value. Working paper, Pennsylvania State University.

Johnson, S. (1997). An Empirical Analysis of the Determinants of Corporate Debt Ownership Structure. The Journal of Financial and Quantitative Analysis, 32(1), pp. 47-69.

Johnson, S. (2003). Debt Maturity and effects of Growth Opportunities and Liquidity Risk on Leverage. Review of Financial Studies, 16(1), pp. 209-236.

Joeveer, K. (2013). Firm, Country and Macroeconomic Determinants of Capital Structure: Evidence from Transition Economies. Journal of Comparative Economics, 41(1), pp. 294-308.

Kim, W., and E. Sorensen (1986). Evidence on the Impact of the Agency Costs of Debt on Corporate Debt Policy. Journal of Financial and Quantitative Analysis, 21(2), pp. 131-144.

Kirch, G., and P. Soares (2012). Determinants of Corporate Debt Maturity in South America: Do Institutional Quality and Financial Development Matter?. Journal of Corporate Finance, 18(4), pp. 980-993.

Körner, P. (2007). The Determinants of Corporate Debt Maturity Structure: Evidence from Czech Firms. Czech Journal of Economics and Finance, 57(34), pp. 142-158.

Lasfer, M. (1999). Debt Structure, Agency Costs and Firm's Size: An Empirical Investigation. Working paper, City University Business School, London

Leland, H. (1998). Agency Costs, Risk Management and Capital Structure. Journal of Finance, 53(4), pp. 1213-1243.

Leland, H., and K. Toft (1996). Optimal Capital Structure, Endogenous Bankruptcy, and the Term Structure of Credit Spreads. Journal of Finance, 51(3), pp. 987-1019.

Marchica, M. (2008). On the relevance of ownership structure in determining the maturity of debt. SSRN working paper series

Megginson, W. (2010). Privatization and Finance. Annual Review of Financial Economics, 2(1), pp. $145-174$.

Megginson, W. (2017). Privatization, State Capitalism, and State Ownership of Business in the 21st century. Foundations and Trends in Finance, forthcoming.

Mokhova, N., and M. Zinecker (2014). Macroeconomic Factors and Corporate Capital Structure. Procedia - Social and Behavioral Sciences, Vol. 110, pp. 530-540.

Morris, J. (1992). Factors affecting the Maturity Structure of Corporate Debt. Working Paper, College of Business and Administration, University of Colorado at Denver.

Muñoz, J., and S. Sepúlveda (2016). Does Managerial Discretion affect Debt Maturity in Chilean Firms? An Agency Cost and Asymmetric Information Approach. Ecos de Economia: A Latinamerican Journal of Applied Economics, 20(43), pp. 65-87.

Myers, S. (1977). Determinants of Corporate Borrowing. Journal of Financial Economics, 5(2), pp. 147175.

Myers, S., and N. Majluf (1984). Corporate Financing and Investment Decisions when Firms have Information that Investors do not have. Journal of Financial Economics, 13(2), pp. 187-221.

Orman, C., and B. Köksal (2017). Debt Maturity across Firm Types: Evidence from a Major Developing Economy. Emerging Markets Review, 30, pp. 169-199.

Ozkan, A. (2000). An Empirical Analysis of Corporate Debt Maturity Structure. European Financial Management, 6(2), pp. 197-212.

Ozkan, A. (2002). The Determinants of Corporate Debt Maturity: Evidence from UK firms. Applied Financial Economics, 12(1), pp. 19-24.

Park, C. (2000). Monitoring and Structure of Debt Contracts. Journal of Finance, 55(5), pp. 2157-2195.

Rajan, R., and A. Winton (1995). Covenants and Collateral as Incentives to Monitor. Journal of Finance, 50(4), pp. 1113-1146.

Saona, P., and E. Vallelado (2005). Ownership Structure and Growth Opportunities as Determinants of Bank Debt: Evidence from Chilean companies. Management Research: Journal of the Iberoamerican Academy of Management, 3(2), pp.121-136.

Saona, P., and E. Vallelado (2014). Is Bank-Debt Maturity Contingent on the Financial System?. Academia Revista Latinoamericana de Administración, 27(2), pp.183-208. 
REMEF (The Mexican Journal of Economics and Finance)

Saona, P., M. Jara, and M. Moreno (2014). Firm Size as Determinant of the Nonlinear Relationship Between Bank Debt and Growth Opportunities: The Case of Chilean Public Firms. Emerging Markets Finance Trade, Vol. 50(1), pp. 265-293.

Scherr, F., and H. Hulburt (2001). The Debt Maturity Structure of Small Firms. Financial Management, 30(1), pp. 85-111.

Shleifer, A., and R. Vishny (1986). Large Shareholders and Corporate Control. Journal of Political Economy, 94(3), pp. 461-88.

Soares, P. (2009). Are Leverage and Debt Maturity Complements or Substitutes? Evidence from Latin America. Revista de Administración, 10(6), pp. 4-24.

Stohs, M., and D. Mauer (1996). The Determinants of Corporate Debt Maturity Structure. Journal of Business, 69(3), pp. 279-312.

Tanaka, T. (2015). Managerial Discretion and the Maturity Structure of Corporate Public Debt: Evidence from Japan. Working paper, Ritsumeikan University.

Titman, S. (1992). Interest Rate Swaps and Corporate Financing Choices. Journal of Finance, 47(4), pp. $1503-1516$.

Tobin, J. (1958). Estimation of relationships for limited dependent variables. Econometrica, 26(1), pp. 24-36.

Turk, R. (2016). Legal systems, Capital Structure, and Debt Maturity in Developing Countries. Corporate Governance: An International Review, 24(2), pp. 130-144. 